\title{
Economical Insulation Layer of the Secondary Pump Lines in the Subway Central Cooling System
}

\author{
Yin Hua ${ }^{1, ~ a ~, ~ G u o ~ H u a f a n g ~}{ }^{1, b}$, Lin Zhenrong ${ }^{1, \mathrm{c}}$, Zeng Bo ${ }^{2, \mathrm{~d}}$ \\ ${ }^{1}$ Key Laboratory of Renewable Energy, Guangzhou Institute of Energy Conversion, Chinese \\ Academy of Science, No. 2 Nengyuan Rd. Wushan, Tianhe District, Guangzhou 510640, PR China; \\ ${ }^{2}$ Guangzhou Nikey Electric Co., Ltd, Guangzhou 510640, PR China \\ a yinhua@ms.giec.ac.cn, ${ }^{\mathrm{b}}$ guohf@ms.giec.ac.cn, ${ }^{\mathrm{c}}$ linzr@ms.giec.ac.cn, \\ nikey002@nikeychina.com
}

\begin{abstract}
Keywords: variable secondary pump water system, optimization model, thermoeconomics cost, insulation thickness.

Abstract. The economical insulation thickness of the secondary pump lines in the subway system was calculated and analyzed based on the established optimization model of the secondary pump water system and the principle of lowest thermoeconomics cost. The main influencing parameters of the optimal insulation thickness were disclosed, including station loads, transportation radius, tunnel air temperature, tunnel wind speed, supply water temperature, supply-return water temperature difference, heat conducitivity coefficient of the insulation layer, and inner diameter of the pipeline. The loss of refrigeration capacity in the supply and return pipes of the secondary pump water system varies significantly because of the supply-return water temperature difference (generally $\geq 5{ }^{\circ} \mathrm{C}$ ), thereby resulting in a large gap in the economical insulation thickness. Therefore, calculating the insultion thickness of the supply and return pipes by combining their characteristics is recommended.
\end{abstract}

\section{Introduction}

The subway central cooling system centralizes the deployment of air-conditioning refrigeration systems to different subway stations and transports the required air-conditioning cold water to the air-conditioning facilities of stations from the central cooling station through cold water pipes. It can adapt to the changing cold loads by adjusting the total cold water flow and the water chiller in the central cooling station, thus maintaining the high efficiency of the water chiller. The centralized cooling system has certain advantages over the decentralized cooling system, in environmental protection, landscape, and operation management because it does not require large cool chillers and cooling towers outside the stations. However, the uniqueness of the central cooling system introduces the following problems, which must be addressed by designers. 1) The surface coefficient of the heat transfer of the insulation layer is higher than that of the conventional running pipe given the high-temperature and high-velocity piston wind in the subway tunnels. Meanwhile, the long-distance transportation (radius $=1500-2500 \mathrm{~m}$ ) results in considerable refrigeration capacity loss of cold water and running cost of the water pump. 2) The insulation shall resist the long-term piston wind erosion in subway tunnels. Moreover, the pipe size requirement is precise, hence the high investment and maintenance cost of insulation pipelines and water pumps [1]. Therefore, the operating parameters related to the operating and investment costs of cold water transport pipelines should be optimized.

Thermoeconomic analysis is a new method that optimizes the energy system by combining exergy and economic analyses. It considers the exergy cost of the energy system scientifically and accurately, searches the optimal running mode of the energy system, and provides the optimal system operating parameters $[2,3]$. The design optimization model of the variable secondary pump water system and cold water transport pipelines was established using thermoeconomic analysis, which analyzed the optimal insulation thickness on pipelines. A case study was carried out subsequently. 


\section{Establishment of the Optimization Model}

Establishment of Thermoeconomic Analysis Model. The thermoeconomic analysis of the cold water transport system in subways was carried out using the black-box model. The model is shown in Fig. 1, where $\mathrm{Ex}_{1}$ is the input exergy of the system, $\mathrm{Ex}_{2}$ is the effective exergy gained by the system, $\mathrm{c}_{1}$ and $\mathrm{c}_{2}$ are the unit exergy costs of $\mathrm{Ex}_{1}$ and $\mathrm{Ex}_{2}$, respectively, $\mathrm{W}_{\text {pump }}$ is the input power of the water pump, $c_{\mathrm{e}}$ is the unit cost of electricity consumption, and $\mathrm{Z}_{\mathrm{L}}$ is the annual costs of water pump and pipes.

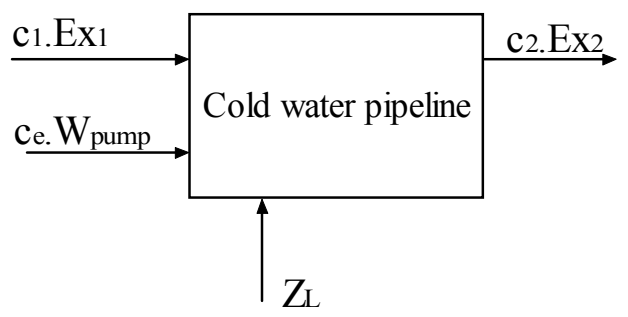

Fig. 1 Thermoeconomic analysis model of the cold water transport system

The cost equation of this system is

$c_{2} E x_{2}=c_{1} E x_{1}+c_{y} W_{p u m p}+Z_{L}$.

Equation (1) shows that the unit price (yuan/W) of cold exergy is

$c_{2}=\frac{c_{1} \bar{E} x_{1}+c_{e} w_{v u m p}+Z_{2}}{E x_{2}}$

The following equations can be obtained according to the exergy analysis model of the cold water transport system in Fig. 2:

$$
\begin{aligned}
& E x_{1}=E x_{\text {pnin }}-E x_{\text {pn,retout }} \\
& E x_{2}=E x_{\text {pnout }}-E x_{\text {pn,retin }}
\end{aligned}
$$

where $\mathrm{Ex}_{\mathrm{pn} \text {,in }}$ is the inflow exergy of chilled water (W), $\mathrm{Ex}_{\mathrm{pn}, \text { out }}$ is the outflow exergy of chilled water (W), Ex $x_{\mathrm{pn}, \text { ret,in }}$ is the inflow exergy of backwater (W), and $\mathrm{Ex}_{\mathrm{pn}, \text { ret,out }}$ is the outflow exergy of backwater (W).

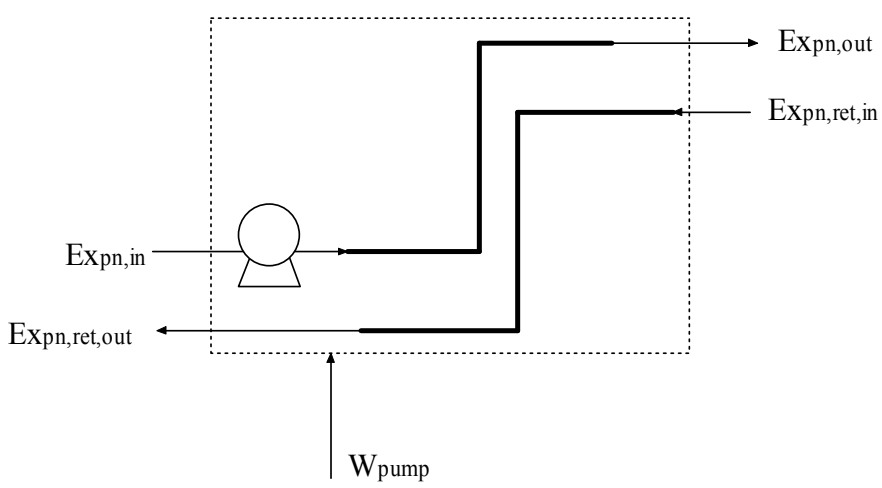

Fig. 2 Exergy analysis model of cold water transport system

The dry-bulb temperature was $32.5^{\circ} \mathrm{C}$ or $305.65 \mathrm{~K}$ outside the air-conditioning station. The exergy of the different water flows was calculated by taking $305.65 \mathrm{~K}$ and $101.325 \mathrm{kPa}$ as the reference.

Exergy of inflow chilled water:

$$
E x_{p m, i n}=Q_{p n, i n}\left(_{T_{m, i n}}^{T_{0}} \quad\right. \text { 1) }
$$

Exergy of outflow chilled water: 


$$
E x_{p n, \text { out }}=\left(Q_{p r i n-} \Delta Q_{1}\right)\left(\frac{T_{0}}{T_{\text {pnout }}}-1\right)
$$

Exergy of backwater inflow:

$$
E x_{p n, \text { ret,in }}=Q_{p n, \text { ret,in }}\left(\begin{array}{cc}
T_{0} & 1)
\end{array}\right.
$$

Exergy of backwater outflow:

$$
E x_{\text {pnrot,out }}=\left(Q_{\text {pnretin- }} \Delta Q_{2}\right)\left(\frac{T_{0}}{T_{\text {pnrst,out }}}-1\right)
$$

where $\mathrm{Q}$ is the refrigerating capacity of the chilled water or backwater $(\mathrm{w}), \mathrm{T}$ is the temperature of the chilled water or backwater $(\mathrm{K}), \Delta \mathrm{Q}_{1}$ is the cooling loss in the chilled water pipe (W), and $\Delta \mathrm{Q}_{2}$ is the cooling loss in the backwater pipe (W).

$$
Q_{p n \text { in }}=1000 Q_{\mathrm{load}}+\Delta Q_{1}
$$

$Q_{\text {pnretin }}=0$,

$\mathrm{Q}_{\text {cold load }}$ is the cold load at stations $(\mathrm{kW})$.

The volume flow of cold water is $\left(\mathrm{m}^{3} / \mathrm{s}\right)$

$$
\mathrm{G}=\underset{\mathrm{cp}_{7} \Delta \mathrm{ta}_{\mathrm{1}}}{1000 \mathrm{Q}_{\mathrm{cold}} \mathrm{lad}+\Delta \mathrm{Q}_{1}}
$$

where $\Delta \mathrm{t}$ is the supply-return water temprature difference $\left({ }^{\circ} \mathrm{C}\right), \mathrm{cp}_{1}$ is the specific heat of the cold water $\left(\mathrm{J} /\left[\mathrm{kg} .{ }^{\circ} \mathrm{C}\right]\right)$, and $\rho_{1}$ is the density of the cold water $\left(\mathrm{kg} / \mathrm{m}^{3}\right)$.

$$
u_{1}=\frac{G}{\frac{G}{t^{2}} d_{1}^{2}}
$$

where $u_{1}$ is the flow rate of chilled water or backwater $(\mathrm{m} / \mathrm{s})$, and $d_{1}$ is the inner diameter of the chilled water pipe or backwater pipe (m).

$$
\begin{aligned}
& T_{\text {pnout }}=T_{p n, i n} \quad \begin{array}{c}
\Delta Q_{1} \\
T_{1} c p_{1} \\
\end{array} Q_{2} \\
& T_{p n, \text { rot,out }}=T_{p n, \text { rot,in }} \quad \begin{array}{c}
\Delta Q_{2} \\
\text { cepp }
\end{array}
\end{aligned}
$$

Cool Loss in the Transport Pipelines. The cooling loss of chilled water includes heat convection-induced loss, radiation-induced loss, and the converted heats of pump power:

$$
\Delta Q_{1}=\left(\Delta q_{\text {heat transfer:1 }}+\Delta q_{\text {radlation } 1}+\Delta q_{\text {pump transfer, } 1}\right) u_{1}
$$

The cooling loss of backwater includes the heat convection-induced loss and the radiation-induced loss:

$$
\Delta Q_{2}=\left(\Delta q_{\text {heat transfor }, 2}+\Delta q_{\text {radiation, } 2}\right) u_{1}
$$

where

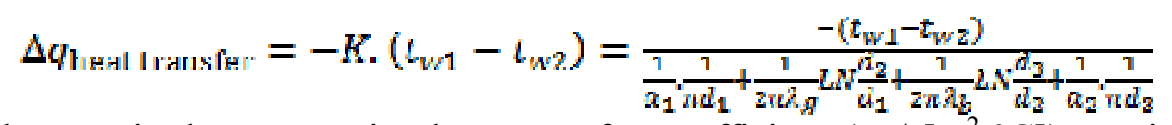

where $\mathrm{K}$ is the convective heat-transfer coefficient $\left(\mathrm{W} /\left[\mathrm{m}^{2} \cdot{ }^{\circ} \mathrm{C}\right]\right), \mathrm{t}_{\mathrm{w} 1}$ is the average temperature of chilled water or backwater in the pipeline $\left({ }^{\circ} \mathrm{C}\right), \mathrm{t}_{\mathrm{w} 2}$ is the air temperature outside the pipelines, which is $30{ }^{\circ} \mathrm{C}$. $\lambda_{\mathrm{g}}$ and $\lambda_{\mathrm{b}}$ are the heat conductivity coefficients of the plastic-coated galvanized steel pipe and the composite aluminum foil centrifugal glass wool rigid section, respectively $\left(\mathrm{W} /\left[\mathrm{m}^{2} \cdot{ }^{\circ} \mathrm{C}\right]\right) . \mathrm{d}_{2}$ and $\mathrm{d}_{3}$ are the outer diameters of the steel pipes and insulation layer (m), respectively; $\alpha_{1}$ and $\alpha_{2}$ are the internal 
and external surface heat transfer coefficients of the chilled water pipe or backwater pipe, respectively $\left(\mathrm{W} /\left[\mathrm{m}^{2} .{ }^{\circ} \mathrm{C}\right]\right)$.

The calculation formula of the convective heat-transfer coefficient at the internal surface of the pipelines is selected when the internal stressed turbulence Dyster-Berthe fluid is heated [4]:

$$
\alpha_{1}-0.023 \frac{A_{1}}{a_{1}}\left(\frac{d_{1} u_{1} \rho_{7}}{\mu_{1}}\right)^{\mathrm{U.3}}\left(\frac{c_{\mathrm{m}} \mu_{1}}{\lambda_{1}}\right)^{0.4}
$$

where $\lambda_{1}$ is the heat conductivity coefficient of the chilled water or backwater under a qualitative temperature $\left(\mathrm{W} /\left[\mathrm{m}^{2}{ }^{\circ} \mathrm{C}\right]\right)$, and $\mu_{1}$ is the viscosity of the chilled water or backwater under a qualitative temperature (Pa.s).

The subway tunnel is perceived as a pipe and the internal surface coefficient of the heat transfer is calculated as the external surface coefficient of the heat transfer of the cold water pipelines. The calculation formula is used when the internal stressed turbulence Dyster-Berthe fluid is cooled:

$$
\alpha_{2}=0.023 \frac{\lambda_{2}}{a_{t}}\left(\frac{d_{8} u_{2} \rho_{2}}{\mu_{2}}\right)^{0.9}\left(\frac{c_{22} \mu_{2}}{\lambda_{2}}\right)^{0.3}
$$

where $\lambda_{2}$ is the heat conductivity coefficient of air under a qualitative temperature $\left(\mathrm{W} /\left[\mathrm{m}^{2} .{ }^{\circ} \mathrm{C}\right]\right), \mu_{2}$ is the viscosity of air under qualitative temperature (Pa.s), $\rho_{2}$ is the air density under qualitative temperature and humidity $\left(\mathrm{kg} / \mathrm{m}^{3}\right), \mathrm{cp}_{2}$ is the specific heat of air under qualitative temperature $\left(\mathrm{J} /\left(\mathrm{kg} .{ }^{\circ} \mathrm{C}\right)\right)$, and $\mathrm{d}_{\mathrm{e}}$ is the tunnel diameter $(\mathrm{m})$.

$$
\Delta q_{\text {radiation }}=-\varepsilon \cdot \pi d_{3} C_{b}\left[\left(\frac{t_{w 33}+273.15}{100}\right)^{4}-\left(\frac{t_{w 4}+2 \pi 3: 15}{100}\right)^{4}\right]
$$

where $t_{\mathrm{w} 3}$ is the external surface temperature of the chilled water or backwater pipes $\left({ }^{\circ} \mathrm{C}\right), \mathrm{t}_{\mathrm{w} 4}$ is the interval wall surface temperature in the tunnel $\left(30^{\circ} \mathrm{C}\right), \varepsilon$ is 0.9 , and $\mathrm{C}_{\mathrm{b}}$ is $5.67 \mathrm{~W} /\left(\mathrm{m}^{2} . \mathrm{K}\right)$.

$$
\Delta q_{\text {pump transfer }}-\frac{W_{\text {punnp }}}{L}
$$

where $\mathrm{W}_{\text {pump }}$ is the input power of the pump (W), and $\mathrm{L}$ is the transportation radius.

\section{Calculation of Power Consumption of Pumps.}

(1) Calculation of on-way resistance P [5]:

$$
\mathrm{P}=\gamma \frac{L}{a_{1}} \frac{\rho u_{1}^{2}}{2}
$$

where $\gamma$ is the on-way resistance coefficient.

The main pipe diameters in the subway central cooling system are all larger than DN100, and the minimum flow velocity is higher than $0.3 \mathrm{~m} / \mathrm{s}$. The Reynolds coefficient is $\operatorname{Re}>10^{4}$, and $\gamma$ can be calculated by the following formula:

$$
\mathrm{Y}=0.11\left(\frac{K_{s}}{a_{1}}\right)^{0.25}
$$

where $\mathrm{K}_{\mathrm{s}}$ is the equivalent roughness of steel pipes computed as $0.25 \times 10^{-3} \mathrm{~m}$.

Supposing the local resistance loss coefficient of pipelines is $\delta$, then the total resistance loss of the pipelines is

$$
\Delta \mathrm{P}=0.58 \rho u_{1}^{2}+0.5 \gamma \frac{L_{1}}{a_{1}} \rho u_{1}^{2}=0.5 \rho u_{1}^{2}\left(\delta+\gamma \frac{L_{1}}{a_{1}}\right)
$$

where $\Delta \mathrm{P}$ is the total resistance loss of pipelines $(\mathrm{Pa})$.

(2) Power consumption of pump

The power consumption of cold water is (W):

$$
W_{\text {punp }}-\frac{\triangle P G}{\eta}
$$

where $\eta$ is the pump efficiency computed as $70 \%$ in this study.

Calculation of Annual Cost 
(1) Total investment cost of pump (yuan) [6]:

$$
\begin{aligned}
& Z_{\text {pump }}=378 \times\left[1+\left(\frac{1-0.808}{1-\eta_{p}}\right)^{3}\right] \times B^{0.71} \\
& \mathrm{~B}=3.6 \Delta P G
\end{aligned}
$$

where $\eta_{P}$ is the exergy efficiency of pump computed as $0.7 . \mathrm{B}$, that is, the product exergy of pump $(\mathrm{kW})$.

(2) Total investment cost of pipelines

The total investment of pipelines includes the expenses for the steel pipe and the insulation layer and damp-proof protection and installation costs [1].

The cost of pipelines per length (yuan $/ \mathrm{m}$ ) is calculated as follows:

$$
z_{g}=F_{g} \pi \theta_{g} \rho_{g}\left(d_{1}+\theta_{g}\right)
$$

where $\rho_{\mathrm{g}}$ is the density of the steel pipe $\left(\mathrm{t} / \mathrm{m}^{3}\right), \mathrm{F}_{\mathrm{g}}$ is the price of the steel pipe (yuan/t), and $\theta_{\mathrm{g}}$ is the thickness of the chilled water or backwater pipe walls $(\mathrm{m})$.

The unit cost per length of the insulation materials (yuan $/ \mathrm{m}$ ) is calculated as follows:

$$
Z_{b}=1.033 F_{b} \pi \theta_{b} \quad\left(d_{1}+2 \theta_{g}+1.033 \theta_{b}\right)
$$

where $\theta_{b}$ is the insulation thickness of the chilled water or backwater pipes $(\mathrm{m}), \mathrm{F}_{\mathrm{b}}$ is the price of the insulation materials $\left(\mathrm{yuan} / \mathrm{m}^{3}\right.$ ), and 1.033 is the regulation factor.

The unit cost per length of the damp-proof protection (yuan/m) is calculated as follows:

$$
Z_{h}=F_{h} \pi\left(d_{1}+2 \theta_{g}+2.1 \theta_{b}+0.0082\right)
$$

where $F_{h}$ is the price of the damp-proof protection materials (yuan $/ \mathrm{m}^{2}$ ), 2.1 is the regulation factor, and 0.0082 is the diameter of the box twine or the thickness of the steel belt (m).

The actual engineering cost can be used to obtain the functional relationship between the unit cost per length of the installation (yuan/m) and the inner diameter $\left(\mathrm{d}_{1}\right)$ :

$$
Z_{a}=\Lambda_{0}+B_{u} d_{1}
$$

where $\mathrm{A}_{0}$ and $\mathrm{B}_{0}$ are the fitting coefficients.

The total investment cost of the unit length of the pipeline is (yuan $/ \mathrm{m}$ ):

$$
Z_{g l}=Z_{g}+Z_{b}+Z_{h}+Z_{a}
$$

(3) Annaul cost of water pump and pipelines (yuan/s)

In thermoeconomic analysis, the total system investment $(Z)$ must be converted into annual repay $\operatorname{cost}\left(\mathrm{Z}_{\mathrm{L}}\right)$ equally in the economic life cycle, which is called the equal annual installment (yuan/s) and computed as follows:

$$
Z_{L}=\frac{\psi \cdot f}{H .3600}\left(Z_{\text {pump }}+Z_{g l, d} \cdot L+Z_{g l, r} \cdot L\right)=\zeta . Z
$$

where $\psi$ is the system maintenance factor (1.06), $\mathrm{Z}_{\mathrm{gl}, \mathrm{d}}$ is the investment cost of the unit length of the chilled waterpipe, $\mathrm{Z}_{\mathrm{gl}, \mathrm{r}}$ is the investment cost of the unit length of the bcakwater pipe, $\mathrm{H}$ is the annual running hours of the system $(8700 \mathrm{~h}), \xi$ is the repay factor $(1 / \mathrm{s})$, and $\mathrm{f}$ is the annual factor, which is calculated as [7]

$$
\begin{aligned}
& \mathrm{f}=\left[\begin{array}{cc}
q^{(k+\tau)}-1 & q^{\tau}-1 \\
(q-1), q(k+\tau) & (q-1) q^{\tau}
\end{array}\right]^{1} \\
& \mathrm{q}=\left(\begin{array}{lll}
1 & 1 & \underset{100}{i n}
\end{array}\right)\left(\begin{array}{lll}
1 & 100
\end{array}\right)
\end{aligned}
$$

where $\tau$ is the construction period of the system ( 1 year), $\mathrm{k}$ is the number of installments ( 5 years), in is the interest rate $(8 \%)$, and $r i$ is the inflation rate $(5 \%)$. 
Objective Function of the Optimization Model and its Constraints. The objective function is the unit exergy cost of the product:

$$
c_{2}=\min \left(\frac{c_{1} E x_{1}+c_{e W_{\text {pump } p: n}}+z_{L}}{E x_{2}}\right)
$$

Constraint 1: The efficiency and parameters of the pump select available engineering data. data.

Constraint 2: The performance of the steel pipe and insulation materials select available engineering

Constraint 3: The insultion thickness is larger than the anti-condensation thickness and the pipe size after the use of insulation layer satisfies the equipment limits.

Constraint 4: The temperature difference at the end of the pipelines must satisfy the technological requirements.

Optimization Variables. The chilled water and backwater flow, and the insulation thickness of chilled water and backwater pipe are the optimization variables in the system. When the cooling loss of pipelines is smaller than $0.1 \%$ of the station loads, it is taken as the operation convergence.

\section{Case Study}

A case study was carried out based on the pipeline from the central cooling station of the $4 \#$ subway central cooling system in Guangzhou to the south of the Higher Education Mega Center. The cooling radius is $1500 \mathrm{~m}$, and the maximum cold loads at the station is $2280 \mathrm{~kW}$. The supply water temperature and supply water temperature difference at the cooling station are $7^{\circ} \mathrm{C}$ and $5{ }^{\circ} \mathrm{C}$, respectively. A few of the coefficients and their corresponding economic parameters in the optimization model are shown in Table 1. The calculated results are listed in Table 2 ( the maximum insulation thickness is set at $\leq 90$ $\mathrm{mm}$, and the cooling loss in the pipeline is the cooling loss in the entire pipeline).

Table 1 Coefficients and corresponding economic parameters in the optimization model

\begin{tabular}{|c|c|c|c|c|c|c|c|}
\hline $\begin{array}{c}\mathrm{c}_{1} \\
(\text { yuan } / \mathrm{kW})\end{array}$ & $\begin{array}{c}\mathrm{c}_{\mathrm{e}} \\
(\text { yuan/kW) }\end{array}$ & $\begin{array}{c}\mathrm{F}_{\mathrm{g}} \\
(\text { yuan/W) }\end{array}$ & $\begin{array}{c}\mathrm{F}_{\mathrm{b}} \\
\left(\mathrm{yuan} / \mathrm{m}^{3}\right)\end{array}$ & $\begin{array}{c}\mathrm{F}_{\mathrm{h}} \\
\left(\mathrm{yuan} / \mathrm{m}^{2}\right)\end{array}$ & $\begin{array}{c}\lambda_{\mathrm{g}} \\
\left(\mathrm{W} /\left(\mathrm{m}^{2} .{ }^{\circ} \mathrm{C}\right)\right)\end{array}$ & $\begin{array}{c}\lambda_{\mathrm{b}} \\
\left(\mathrm{W} /\left(\mathrm{m}^{2} .{ }^{\circ} \mathrm{C}\right)\right)\end{array}$ & $\delta$ \\
\hline 2.12 & 0.72 & 5500 & 5000 & 25 & 45 & 0.045 & 30 \\
\hline
\end{tabular}

Table 2 Calculated results

\begin{tabular}{|c|c|c|c|c|c|}
\hline & $\begin{array}{c}\mathrm{c}_{2} \\
(\mathrm{yuan} / \mathrm{W})\end{array}$ & $\begin{array}{c}\text { Cool loss in } \\
\text { pipeline } \\
(\mathrm{kW})\end{array}$ & $\begin{array}{c}\text { Economic flow } \\
\text { rate } \\
(\mathrm{m} / \mathrm{s})\end{array}$ & $\begin{array}{c}\text { Innder } \\
\text { diameter } \\
(\mathrm{mm})\end{array}$ & $\begin{array}{c}\text { Economic insulation } \\
\text { thickness } \\
(\mathrm{mm})\end{array}$ \\
\cline { 1 - 4 } Supply & $2.31 \times 10^{-3}$ & 33.24 & 2.21 & 250 & 90 \\
\cline { 1 - 3 } Return & 41.08 & 1.83 & 275 & 58 \\
\hline
\end{tabular}

\section{Analysis of Influencing Factors}

To elucidate further the influences of different factors on economic flow rate and economic insulation thickness, the main factors were analyzed in this study. The results are shown in Tables 310.

Effect of Station Loads. The results under different station loads $(2580 \mathrm{~kW}, 2080 \mathrm{~kW}, 1580 \mathrm{~kW}$, $1080 \mathrm{~kW}$, and $650 \mathrm{~kW}$ ), with the other conditions constant, are shown in Table 3. 
Table 3 Influences of station loads

\begin{tabular}{|c|c|c|c|c|c|}
\hline \multirow{2}{*}{ Station loads $(\mathrm{kW})$} & \multirow{2}{*}{$\begin{array}{c}\mathrm{c}_{2} \\
\left(\times 10^{-3} \text { yuan/W) }\right.\end{array}$} & \multicolumn{2}{|c|}{$\begin{array}{c}\text { Economic flow rate } \\
(\mathrm{m} / \mathrm{s})\end{array}$} & $\begin{array}{c}\text { Economic insulation thickness } \\
(\mathrm{mm})\end{array}$ \\
\cline { 3 - 6 } & & Supply & Return & Supply & Return \\
\hline 2580 & 2.36 & 2.50 & 2.07 & 90 & 61 \\
\hline 2080 & 2.28 & 2.02 & 1.67 & 87 & 55 \\
\hline 1580 & 2.21 & 1.53 & 1.28 & 75 & 49 \\
\hline 1080 & 2.16 & 1.05 & 0.87 & 61 & 40 \\
\hline 650 & 2.14 & 0.63 & 0.52 & 48 & 31 \\
\hline
\end{tabular}

Table 3 shows that the cold water flow rate increases from $0.63 / 0.52 \mathrm{~m} / \mathrm{s}$ to $2.50 / 2.07 \mathrm{~m} / \mathrm{s}$, the insulation thickness increases from $48 / 31 \mathrm{~mm}$ to $90 / 61 \mathrm{~mm}$, and $\mathrm{c}_{2}$ increases from $2.14 \times 10^{-3} \mathrm{yuan} / \mathrm{W}$ to $2.36 \times 10^{-3}$ yuan/ $\mathrm{W}$ with the increase in station loads.

Effect of Transportation Radius. The results under different transportation radii $(2500 \mathrm{~m}, 2000$ $\mathrm{m}, 1600 \mathrm{~m}$, and $1000 \mathrm{~m}$ ), with the other conditions constant, are shown in Table 4.

Table 4 Influences of transportation radius

\begin{tabular}{|c|c|c|c|c|c|}
\hline \multirow{2}{*}{$\begin{array}{c}\text { Transportation radius } \\
(\mathrm{m})\end{array}$} & \multirow{2}{*}{$\begin{array}{c}\mathrm{c}_{2} \\
\left(\times 10^{-3} \mathrm{yuan} / \mathrm{W}\right)\end{array}$} & \multicolumn{2}{|c|}{$\begin{array}{c}\text { Economic flow rate } \\
(\mathrm{m} / \mathrm{s})\end{array}$} & \multicolumn{2}{|c|}{$\begin{array}{c}\text { Economic insulation thickness } \\
(\mathrm{mm})\end{array}$} \\
\cline { 3 - 6 } & & Supply & Return & Supply & Return \\
\hline 2500 & 2.41 & 2.21 & 1.83 & 77 & 45 \\
\hline 2000 & 2.36 & 2.21 & 1.83 & 83 & 50 \\
\hline 1600 & 2.32 & 2.21 & 1.83 & 89 & 53 \\
\hline 1000 & 2.26 & 2.21 & 1.83 & 90 & 69 \\
\hline
\end{tabular}

Table 4 indicates that $c_{2}$ increases from $2.26 \times 10^{-3}$ yuan/W to $2.41 \times 10^{-3}$ yuan/W as the transportation radius increases, whereas the return insulation thickness decreases from 90/69 $\mathrm{mm}$ to $77 / 45 \mathrm{~mm}$. Meanwhile, the economic flow rates of the supply and return water are maintained at $2.21 / 1.83 \mathrm{~m} / \mathrm{s}$. This is mainly because the cooling loss in the pipelines accounts for a small proportion of the cooling loads of the station $(<0.1 \%)$.

Effect of Air Temperature and Wind Speed in the Tunnel. The results under different temperatures $\left(28^{\circ} \mathrm{C}, 30^{\circ} \mathrm{C}, 32^{\circ} \mathrm{C}, 35^{\circ} \mathrm{C}, 38^{\circ} \mathrm{C}\right.$, and $\left.40^{\circ} \mathrm{C}\right)$ and different wind velocities $(7.50 \mathrm{~m} / \mathrm{s}$, $11.25 \mathrm{~m} / \mathrm{s}$, and $15.00 \mathrm{~m} / \mathrm{s}$ ), with the other conditions constant, are shown in Table 5.

Table 5 Influences of air temperature and wind speed in the tunnel

\begin{tabular}{|c|c|c|c|c|c|c|}
\hline $\begin{array}{c}\text { Air } \\
\text { temperature } \\
\left({ }^{\circ} \mathrm{C}\right)\end{array}$ & $\begin{array}{c}\text { Wind } \\
\text { speed } \\
(\mathrm{m} / \mathrm{s})\end{array}$ & \multicolumn{2}{|c|}{$\begin{array}{c}\mathrm{c}_{2} \\
\left(\times 10^{-3} \text { yuan } / \mathrm{W}\right)\end{array}$} & $\begin{array}{l}\text { Cooling loss in pipelines } \\
(\mathrm{kW})\end{array}$ & \multicolumn{2}{|c|}{$\begin{array}{c}\text { Insulation thickness } \\
(\mathrm{mm})\end{array}$} \\
\hline 28 & 7.50 & 2.27 & 32.71 & 40.20 & 78 & 48 \\
\hline 30 & 7.50 & 2.27 & 34.62 & 43.09 & 81 & 51 \\
\hline 32 & 11.25 & 2.27 & 36.63 & 46.49 & 87 & 55 \\
\hline 35 & 11.25 & 2.27 & 39.75 & 65.58 & 90 & 58 \\
\hline 40 & 15.00 & 2.27 & 47.28 & 84.36 & 90 & 61 \\
\hline
\end{tabular}


Table 5 shows that $c_{2}$ basically remains the same (it increases insignificantly) with the increase of the air temperature and wind speed in the tunnel, whereas the cooling loss in the pipelines and the insulation thickness increase significantly. The cooling loss increases from $32.71 / 40.20 \mathrm{~kW}$ to $47.28 / 84.36 \mathrm{~kW}$, while the insulation thickness increases from $78 / 48 \mathrm{~mm}$ to $90 / 61 \mathrm{~mm}$. Moreover, the cooling loss in the pipelines and insulation thickess influence $\mathrm{c}_{2}$ slightly.

Effects of Supply Water Temperature and Supply-Return Water Temperature Difference. The results under different supply water temperatures $\left(5^{\circ} \mathrm{C}, 6{ }^{\circ} \mathrm{C}, 7^{\circ} \mathrm{C}, 8^{\circ} \mathrm{C}\right.$, and $\left.9^{\circ} \mathrm{C}\right)$, with the other conditions constant, are shown in Table 6. The results under different supply-return water temperatures $\left(5^{\circ} \mathrm{C}, 6^{\circ} \mathrm{C}, 7^{\circ} \mathrm{C}, 8^{\circ} \mathrm{C}\right.$, and $\left.9^{\circ} \mathrm{C}\right)$, with the other conditions constant, are shown in Table 7.

Table 6 Influences of supply water temperature

\begin{tabular}{|c|c|c|c|c|c|c|c|}
\hline \multirow{2}{*}{$\begin{array}{c}\text { Supply water } \\
\text { temperature } \\
\left({ }^{\circ} \mathrm{C}\right)\end{array}$} & $\begin{array}{c}\mathrm{c}_{2} \\
\left(\times 10^{-3} \text { yuan/W) }\right.\end{array}$ & \multicolumn{2}{|c|}{$\begin{array}{c}\text { Cooling loss in } \\
\text { pipelines }(\mathrm{kW})\end{array}$} & \multicolumn{2}{|c|}{ Flow rate $(\mathrm{m} / \mathrm{s})$} & \multicolumn{2}{|c|}{$\begin{array}{c}\text { Insulation thickness } \\
(\mathrm{mm})\end{array}$} \\
\cline { 3 - 8 } & & Supply & Return & Supply & Return & Supply & Return \\
\hline 5 & 2.27 & 36.63 & 46.07 & 1.94 & 1.60 & 87 & 55 \\
\hline 6 & 2.27 & 35.68 & 44.67 & 1.94 & 1.60 & 85 & 54 \\
\hline 7 & 2.27 & 34.73 & 43.25 & 1.94 & 1.60 & 83 & 53 \\
\hline 8 & 2.27 & 33.77 & 41.79 & 1.94 & 1.60 & 82 & 51 \\
\hline 9 & 2.27 & 32.78 & 40.31 & 1.94 & 1.60 & 80 & 50 \\
\hline
\end{tabular}

Table 7 Influences of supply-return water temperature difference

\begin{tabular}{|c|c|c|c|c|c|c|c|}
\hline $\begin{array}{c}\text { Supply-return water } \\
\text { temperature } \\
\text { difference } \\
\left({ }^{\circ} \mathrm{C}\right)\end{array}$ & \multirow{2}{*}{$\begin{array}{c}\mathrm{c}_{2} \\
\left(\times 10^{-3} \text { yuan/W) }\right.\end{array}$} & \multicolumn{2}{|c|}{$\begin{array}{c}\text { Cooling loss in } \\
\text { pipelines }(\mathrm{kW})\end{array}$} & \multicolumn{2}{|c|}{ Flow rate $(\mathrm{m} / \mathrm{s})$} & \multicolumn{2}{|c|}{$\begin{array}{c}\text { Insulation } \\
\text { thickness }(\mathrm{mm})\end{array}$} \\
\cline { 3 - 8 } & & Supply & Return & Supply & Return & Supply & Return \\
\hline 5 & 2.27 & 34.73 & 43.25 & 1.94 & 1.60 & 83 & 53 \\
\hline 6 & 2.27 & 34.73 & 41.80 & 1.94 & 1.60 & 84 & 51 \\
\hline 7 & 2.27 & 34.73 & 40.31 & 1.94 & 1.60 & 84 & 50 \\
\hline 8 & 2.27 & 34.73 & 38.79 & 1.94 & 1.60 & 83 & 48 \\
\hline 9 & 2.27 & 34.73 & 37.25 & 1.94 & 1.60 & 83 & 46 \\
\hline
\end{tabular}

Table 6 shows that the cooling loss in the pipelines decrease continuously from $36.63 / 46.07 \mathrm{~kW}$ to $32.78 / 40.31 \mathrm{~kW}$, and the corresponding insulation thickness of the supply-return water pipe decreases gradually from $87 / 55 \mathrm{~mm}$ to $80 / 50 \mathrm{~mm}$ with the increase in supply water temperture. Therefore, the investment cost of pipelines declines contiuously. When the air-conditioning terminal is comprehensively considered, the temperature difference at the terminal decreases due to the increase in the supply water temperature, thereby increasing the required cooling exchange area. Therefore, other systems, such as the air-conditioning terminal, must be considered when determining the supply water temperature.

Table 7 shows that the cooling loss of the supply pipes remains stable at $34.73 \mathrm{~kW}$ and the insulation thickness fluctuates slightly between $83 \mathrm{~mm}$ and $84 \mathrm{~mm}$ with the increase in the supply-return temperature difference. However, the cooling loss in the return pipes decreases sharply from $43.25 \mathrm{~kW}$ to $37.25 \mathrm{~kW}$, and the corresponding insulation thickness of the return pipe decreases continuously from $53 \mathrm{~mm}$ to $46 \mathrm{~mm}$ (because the cooling loss decreases with the reduction of the temperature difference between the water in the return pipe and the air in the tunnel). Similarly, the heat exchange effect at the air-conditioning terminal must be considered comprehensively to determine the supply-return water temperature difference. 
Effect of Heat Conductivity Coefficient of the Insulation Layer. The results under the different heat conductivity coefficients of the insulation layer $\left(0.0035 \mathrm{~W} /\left(\mathrm{m}^{2} .{ }^{\circ} \mathrm{C}\right), 0.0040 \mathrm{~W} /\left(\mathrm{m}^{2} .{ }^{\circ} \mathrm{C}\right), 0.0045\right.$ $\mathrm{W} /\left(\mathrm{m}^{2} .{ }^{\circ} \mathrm{C}\right), 0.0050 \mathrm{~W} /\left(\mathrm{m}^{2} .{ }^{\circ} \mathrm{C}\right)$, and $\left.0.0055 \mathrm{~W} /\left(\mathrm{m}^{2} .{ }^{\circ} \mathrm{C}\right)\right)$, with the other conditions costant, are shown in Table 8.

Table 8 Influences of heat conductivity coefficient of the insulation layer

\begin{tabular}{|c|c|c|c|c|c|c|c|}
\hline \multirow{2}{*}{$\begin{array}{c}\text { Heat } \\
\text { conductivity } \\
\text { coefficient of } \\
\text { insulation layer } \\
\left(\mathrm{W} /\left(\mathrm{m}^{2} .{ }^{\circ} \mathrm{C}\right)\right)\end{array}$} & \multirow{2}{*}{$\begin{array}{c}\mathrm{c}_{2} \\
\left(\times 10^{-3} \text { yuan } / \mathrm{W}\right)\end{array}$} & \multicolumn{2}{|c|}{$\begin{array}{l}\text { Cooling loss in pipelines } \\
\qquad(\mathrm{kW})\end{array}$} & \multicolumn{2}{|c|}{ Flow rate $(\mathrm{m} / \mathrm{s})$} & \multicolumn{2}{|c|}{$\begin{array}{l}\text { Insulation thickness } \\
(\mathrm{mm})\end{array}$} \\
\hline & & Supply & Return & Supply & Return & Supply & Return \\
\hline 0.0030 & 2.27 & 27.01 & 34.13 & 1.94 & 1.60 & 71 & 45 \\
\hline 0.0035 & 2.27 & 29.71 & 37.33 & 1.94 & 1.60 & 76 & 48 \\
\hline 0.0040 & 2.27 & 32.28 & 40.33 & 1.94 & 1.60 & 80 & 50 \\
\hline 0.0045 & 2.27 & 34.73 & 43.25 & 1.94 & 1.60 & 83 & 53 \\
\hline 0.0050 & 2.27 & 37.11 & 46.01 & 1.94 & 1.60 & 87 & 55 \\
\hline
\end{tabular}

Table 8 shows that $\mathrm{c}_{2}$ remains basically the same with the increase in heat conductivity coefficient of the insulation layer, but the cooling loss in the pipelines increases continuously from $27.01 / 34.13 \mathrm{~kW}$ to $37.11 / 46.01 \mathrm{~kW}$. The insulation thickness of the supply-return water pipelines increases continuoulsy from $71 / 45 \mathrm{~mm}$ to $87 / 55 \mathrm{~mm}$.

Effect of Inner Diameter of Pipelines. The results of the different inner diameters of the supply pipe $(175 \mathrm{~mm}, 225 \mathrm{~mm}, 275 \mathrm{~mm}, 300 \mathrm{~mm}, 325 \mathrm{~mm}$, and $375 \mathrm{~mm})$ and return pipe $(225 \mathrm{~mm}, 250 \mathrm{~mm}$, $300 \mathrm{~mm}, 325 \mathrm{~mm}$, and $375 \mathrm{~mm}$ ), with the other conditions constant, are listed in Tables 9 and 10, respectively.

Table 9 Influences of inner diameter of supply pipe

\begin{tabular}{|c|c|c|c|c|c|}
\hline \multirow{2}{*}{$\begin{array}{c}\text { Inner diameter of the pipes } \\
(\mathrm{mm})\end{array}$} & \multicolumn{2}{|c|}{$\begin{array}{c}\mathrm{c}_{2} \\
\left(\times 10^{-3} \text { yuan/W) }\right.\end{array}$} & \multicolumn{2}{|c|}{ Economic flow rate $(\mathrm{m} / \mathrm{s})$} & \multicolumn{2}{c|}{ Insulation thickness (mm) } \\
\cline { 3 - 6 } & & Supply & Return & Supply & Return \\
\hline 175 & 3.00 & 3.96 & 1.60 & 90 & 54 \\
\hline 225 & 2.27 & 1.94 & 1.60 & 85 & 54 \\
\hline 275 & 2.21 & 1.60 & 1.60 & 77 & 54 \\
\hline 300 & 2.17 & 1.35 & 1.60 & 70 & 53 \\
\hline 325 & 2.16 & 1.15 & 1.60 & 66 & 54 \\
\hline 375 & 2.14 & 0.86 & 1.60 & 61 & 54 \\
\hline
\end{tabular}

Table 10 Influences of inner diameter of return pipe

\begin{tabular}{|c|c|c|c|c|c|}
\hline \multirow{2}{*}{$\begin{array}{c}\text { Inner diameter of the pipes } \\
(\mathrm{mm})\end{array}$} & \multirow{2}{*}{$\begin{array}{c}\mathrm{c}_{2} \\
\left(\times 10^{-3} \text { yuan/W) }\right.\end{array}$} & \multicolumn{2}{|c|}{ Economic flow rate (m/s) } & \multicolumn{2}{|c|}{ Insulation thickness (mm) } \\
\cline { 3 - 6 } & & Supply & Return & & \\
\hline 225 & 2.27 & 1.94 & 2.40 & 83 & 62 \\
\hline 250 & 2.27 & 1.94 & 1.94 & 83 & 57 \\
\hline 300 & 2.27 & 1.94 & 1.35 & 83 & 49 \\
\hline 325 & 2.27 & 1.94 & 1.15 & 83 & 45 \\
\hline 375 & 2.27 & 1.94 & 0.86 & 83 & 33 \\
\hline
\end{tabular}


Table 9 shows that $\mathrm{c}_{2}$ is highly sensitive to the inner diameter of the supply pipe. $\mathrm{c}_{2}$ decreases from $3.00 \times 10^{-3}$ yuan/W to $2.14 \times 10^{-3}$ yuan/W with the increase in inner diameter. Table 10 shows that $\mathrm{c}_{2}$ remains bascially the same (approximately $2.27 \times 10^{-3}$ yuan/W) regardless of the inner diameter of the return pipe. The economic flow rate in the supply and return pipes decreases with the increase in inner diameter from $3.96 \mathrm{~m} / \mathrm{s}$ to $0.86 \mathrm{~m} / \mathrm{s}$ and from $2.40 \mathrm{~m} / \mathrm{s}$ to $0.86 \mathrm{~m} / \mathrm{s}$, respectively. At the same time, the insulation thickness decreases. The insulation thicknesses of the supply and return pipes decrease from $90 \mathrm{~mm}$ to $71 \mathrm{~mm}$ and from $62 \mathrm{~mm}$ to $33 \mathrm{~mm}$, respectively.

\section{Conclusions}

The analysis shows that a specific central cooling system has one optimal insulation thickness. The followig conclusions are drawn from the analysis and calculation:

(1) Station loads, transport radius, tunnel air temperature, tunnel wind speed, supply water temperature, supply-return water temperature difference, the heat conductivity coefficient of the insulation layer, and the inner diameter of pipes are the main factors that influence the optimal insulation thickness.

(2) The unit cost of $\operatorname{Ex}_{2}\left(c_{2}\right)$ is mainly influenced by station loads, transport radius, and the inner diameter of pipes. However, it is insensitive to tunnel air temperature, tunnel wind speed, supply water temperature, the supply-return water temperature difference, the heat conductivity coefficient of the insulation layer, and the diameter of return pipes.

(3) Flow rate is mainly influenced by the cold loads at stations and the pipe radius. Cooling loss only accounts for an extremely small proportion of the total cold loads of stations (generally $<0.1 \%$ ) given the acceptable insulation of pipes. The supply and return rates are insensitive to supply water temperature and insulation coefficients that influence cooling loss significantly.

(4) The economic insulation thicknesses of the supply and return pipes, which are affected by cold water temperature, differ significantly and even reach $50 \mathrm{~mm}$ at maximum. The cooling loss in the supply and return pipes differ to a certain extent. Calculating the insulation thicknesses of the supply and return pipes, by combining their characteristics is recommended.

\section{Acknowledgements}

This study was financially supported by the Guangzhou Science and Technology Program (2017010160583).

\section{References}

[1] J. L. Peng, W. Wu: HV \& AC Vol. 38 (2008), p. 106-112.

[2] R. B. Evans: Energy Vol. 5 (1980), p. 805-821.

[3] V. A. Mazur: Int. J. Exergy Vol. 2 (2005), p. 1-13.

[4] Ch. Y. Bao, in: Research on Central Cooling of city Underground Rail Traffic Station, Master Thesis, University Of Chongqing, Chongqing, China (2012).

[5] M. R. Zhou, L. Q. Deng, in: Fluid mechanics pumps and fans, chapter, 4, China Architecture \& Building Press (1985).

[6] M. A. Lozano, A. Valero, L. Serra, Theory of the exergetic cost and thermoeconomics optimization (Proceedings of the International Symposium ENSEC' 93. Cracow, Polland 1993).

[7] J. L. Silveira, C. E. Tuna: Prog. Energy Combust. Sci. Vol. 29 (2003), p. 479-485. 